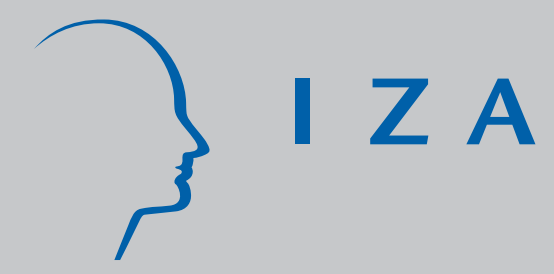

IZADP No. 2042

Living Arrangements in Western Europe:

Does Cultural Origin Matter?

Paola Giuliano

March 2006 


\title{
Living Arrangements in Western Europe: Does Cultural Origin Matter?
}

\author{
Paola Giuliano \\ International Monetary Fund \\ and IZA Bonn
}

Discussion Paper No. 2042

March 2006

\author{
IZA \\ P.O. Box 7240 \\ 53072 Bonn \\ Germany \\ Phone: +49-228-3894-0 \\ Fax: +49-228-3894-180 \\ Email: iza@iza.org
}

\begin{abstract}
Any opinions expressed here are those of the author(s) and not those of the institute. Research disseminated by IZA may include views on policy, but the institute itself takes no institutional policy positions.

The Institute for the Study of Labor (IZA) in Bonn is a local and virtual international research center and a place of communication between science, politics and business. IZA is an independent nonprofit company supported by Deutsche Post World Net. The center is associated with the University of Bonn and offers a stimulating research environment through its research networks, research support, and visitors and doctoral programs. IZA engages in (i) original and internationally competitive research in all fields of labor economics, (ii) development of policy concepts, and (iii) dissemination of research results and concepts to the interested public.
\end{abstract}

IZA Discussion Papers often represent preliminary work and are circulated to encourage discussion. Citation of such a paper should account for its provisional character. A revised version may be available directly from the author. 


\title{
ABSTRACT
}

\section{Living Arrangements in Western Europe: Does Cultural Origin Matter?*}

\begin{abstract}
Why are there such large differences in living arrangements across Western European countries? Conventional economic analyses have not been successful in explaining differences in living arrangements and particularly the dramatic increase in the fraction of young adults living with their parents in Mediterranean Europe. This paper presents a cultural interpretation. I argue that the sexual revolution of the 1970 s - by liberalizing parental attitudes - had a differential impact on living arrangements in Northern and Southern Europe on account of the closer parent-child ties in Southern Europe. Such an explanation can easily explain both the shift in living arrangements over time and also observed North-South differentials. It receives support from data on the living arrangements of second-generation immigrants in the US. Both in 1970 and 2000, by country of origin, the US living arrangements of second-generation immigrants mimic those in Europe across countries; similarly the changes in the US across time by country of origin mimic the European changes. This duplication of the European pattern in a neutral environment, with the same unemployment benefits, the same welfare code and the same macroeconomic conditions suggests a major role for culture in determining living arrangements.
\end{abstract}

JEL Classification: D1, J1, Z13

Keywords: culture, living arrangements, immigrants, family

Corresponding author:

Paola Giuliano

International Monetary Fund

Research Department

700 19th Street NW

Washington, DC 20431

USA

Email: pgiuliano@imf.org

\footnotetext{
* I am particularly grateful to George Akerlof and Alberto Alesina for invaluable support and comments. I would also like to thank Bob Anderson, Larry Blume, Ken Chay, Piero Cipollone, Julian di Giovanni, Barry Eichengreen, Rebecca Hellerstein, Chad Jones, Lalith Munasinghe, Roberto Perotti, Steven Raphael, Luca Rigotti, David Romer, Hui Tong and four anonymous referees for useful comments. The paper has benefited from seminar presentations at the University of California at Berkeley, Boston College, Boston Fed, Cornell University, Columbia University, George Washington University, IIES (Stockholm), New York Fed, SAIS (Johns Hopkins), University of Washington (Seattle), the Econometric Society North American Summer Meeting (2004), the Annual Meeting of the European Economic Association (2004), the NBER-Macroeconomics and Individual Decision Making Conference (2004) and the Society for Economic Dynamics Annual Meeting (2005). Finally, I am grateful to Rossella Palomba of the Institute for Population Research in Italy for providing the data on Italy. The views expressed on this paper are those of the author and do not represent the views of the IMF or IMF policy. All errors are my own.
} 


\section{INTRODUCTION}

In the past thirty years Mediterranean Europe has witnessed a dramatic increase in the fraction of young adults living with their parents. In the early 1970s, the fraction living at home was low and similar across all Western European countries. Today, well over half of all young adults 18-33 year olds live with their parents in Greece, Italy, Portugal and Spain. In contrast, "stay-at-homes" are less than 30 percent in the United Kingdom, France, Germany, the Scandinavian countries, as also in the US. Why Southern Europeans $^{1}$ remain at their parents' home is of primary policy concern, since this postponement of adult life may critically impact the youth labor supply, the overall fertility level and the European pay-as-you-go pension systems. ${ }^{2}$

Why do Mediterranean youth continue to live with their parents while their counterparts in Scandinavian Europe, the US and the UK, do not? A variety of explanations have been suggested in the literature. Some have interpreted the large proportion of Southern European stay-at-homes as tell-tales of unfavorable economic conditions, including both the high costs of housing [Giannelli and Monfardini, 2000; and Ruiz-Castillo and Martinez-Granado, 2002], and poor employment opportunities [Ghidoni, 2002]. A second interpretation relies on high job security. For example, Becker, Bentolila, Fernandes and Ichino [2002] find that children whose father is unemployed are more likely to live independently. In a similar vein, Fogli [2000] shows that children remain with their parents to enjoy household consumption (a public good) and thereby they avoid the credit constraints they would face if they lived alone and went out to work ${ }^{3}$. A third interpretation is provided by Manacorda and Moretti [2002], who argue that a rise in parents' income allows them to offer their children a higher consumption in exchange for their presence at home. Although the children prefer to live on their own, they are willing to exchange some independence for extra consumption. Differences in housing subsidy policies are also an important determinant of living arrangements, in addition to other family policies such as maternity leave and child benefits [Neyer, 2003]. Whether

\footnotetext{
${ }^{1}$ Southern Europe and Mediterranean Europe are used interchangeably to refer to Greece, Italy, Portugal and Spain.

${ }^{2}$ Bentolila and Ichino find that the consumption losses after the termination of a job are much lower in Mediterranean Europe, due to strong family ties.

${ }^{3}$ This is viable because their parents' jobs are secure due to extensive labor market regulations.
} 
young adults attend higher education at universities with on-campus accommodation, as opposed to local universities, can also be a crucial determinant of living arrangements.

This paper presents a cultural interpretation for the dramatic increase in the fraction of young adults staying at home. I argue that the sexual revolution of the 1970s by liberalizing parental attitudes - had a differential impact on living arrangements in Northern and Southern Europe on account of the closer parent-child ties in Southern Europe.

Reher (1998) analyses differences in family structures across Northern and Southern Europe, and argues that in Southern Europe, the Muslim domination emphasized the vertical relationship between generations. Put differently, children's care of their parents in old age and the prolonged stay of children in their parents' home are seen as a manifestation of a "strong family". In Northern Europe, the Reformation and Germanic tradition contributed to the development of a weak family characterized by people who are not reliant on their children in old age and by youth who detach themselves from their parents at a relatively early age.

Until the 1970s there was at least a superficial resemblance on the road to adulthood across all European countries. Youth left home early, typically to get married, and had their first child in their early twenties, if not before. In both Northern and Southern Europe, the family was traditional, and sexual emancipation occurred outside the household. However, in the span of few decades this sequence had changed radically, with striking differences across Northern and Southern Europe. ${ }^{4}$ Today there are two modes of departure from the parental home (Galland 1986): in Northern Europe youth leave their family early, sometimes to live alone, and sometimes to cohabit with significant others; in Southern Europe, the young stay with their parents well into adulthood, and leave only at the time of marriage.

The key question is why the Northern and Southern family systems appear to be similar in the 1970s and why they differ so markedly today. The cultural norm in Southern

\footnotetext{
${ }^{4}$ Several other authors have also studied this uniformity of behavior in the 1970s. For example, both Rydell (2002) and Kiernan (1986) have a comprehensive review of demographic patterns in Western Europe from the 1960s. According to them, leaving home in Western Europe was very uniform around the 1970, and this departure was connected to marriage which was occurring at a young age. As they claim, "a trend toward self-fulfillment and independence was recognized in a context in which the only way of expression was through marriage for all countries"
} 
Europe has always been to leave for marriage. In the 1970s however the family was traditional and strict, and the privacy cost of staying at home was high, creating an impetus for Mediterranean youth to leave home and get married at a relatively early age. The new liberal parenting attitude, most likely ushered in by the sexual revolution, has favored a longer life in the parental household. In particular, Mediterranean youth are now happier living at home and postponing their marriage decisions. On the other hand, in Northern Europe where the cultural norm has always been the independence of the generations, the youth continue to leave home early, notwithstanding emergence of a more liberal family structure. As a consequence, the sexual revolution had a negligible impact on the living arrangements of the Northern European family type ${ }^{5}$.

Since cultural norms, economic conditions, and institutions, are country specific, cross-country differences within Europe cannot be exploited to properly identify the relative importance of this culture hypothesis from more traditional economic explanations. In order to make the cultural identification, I look at the living arrangements of second-generation immigrants in the USA ${ }^{6}$. If cultural norms are persistent, then living arrangements of immigrants to the United States should parallel their counterparts in the home country. In fact, the US provides an ideal context for testing this cultural hypothesis since it contains immigrants from all of the Northern and Southern European countries. Moreover, other likely determinants of living arrangement such as labor and housing market conditions, and welfare programs can be held constant across different immigrant groups. I test the culture hypothesis in two ways. First, I use dummy variables for the immigrants' country of origin as a proxy for culture to predict the fraction of adult youth

\footnotetext{
${ }^{5}$ The sexual revolution is defined as a drastic relaxation in general standards of sexual behavior. On one hand, it is a technological shock, associated with the introduction of the pill and the liberalization of abortion. The pill arrived in Europe in the mid 1960's but it was widely diffused only 5-10 years after (for example it arrived in 1965 in Italy but it was widely diffused only in 1976). The abortion was liberalized in the mid 1970’s-mid 1980’s (1973 in Sweden, 1975 in France, 1976 in Germany, 1978 in Italy and Greece, 1981 in the Netherlands and 1985 in Spain) with the exception of the UK (1967) and some countries that never liberalized (as Portugal and Ireland). On the other hand, the sexual revolution also brought about a change in attitudes towards sexual behavior. That said, "it is clear that attitudes towards sexual behaviour did not change radically for the vast majority of men and women immediately, but only a generation after the "revolution" had begun". (David, 1999). This change in attitudes towards sexual behavior is the focus of this paper. See also Akerlof, Yellen and Katz (1996) and Goldin and Katz $(2000,2002)$ for a timing of the sexual revolution and its economic impact.

${ }^{6}$ Carroll, Rhee and Rhee (1994) study the impact of culture on savings looking at the behavior of first generation immigrants in the USA and they do not find a significant impact of cultural origin. Fernandez and Fogli (2005) study women fertility and female labor force participation looking at second-generation immigrants and find that culture plays an important role in the determination of those two outcomes.
} 
living with their parents. These dummy coefficients measure the extent to which people from immigrant families differ from natives and from each other, and allow a test of whether cultural differences affect living arrangements. Furthermore, I complement this analysis by directly correlating living arrangements in the country of origin - a variable that should reflect the cultural norm of immigrants with respect to family arrangements with the living arrangements of their US immigrant counterparts.

The empirical analysis shows that in both 1970 and 2000, the US living arrangements of second-generation immigrants mimic the living arrangements of their respective counterparts in Europe. Moreover, the evolution of living arrangements in the US over this time period follows a similar pattern to the evolution of such a behavior in the original countries. Only 23\% of US natives lived with their parents in 1970 and this percentage rose only slightly to $27 \%$ by 2000 . A similar pattern is observed for the UK (from $21 \%$ to $22 \%$ ) and for Scandinavian nations (from 15\% to $18 \%$ ). However, this proportion increased dramatically for all Southern European second generation immigrants. Particularly it went from $25 \%$ to $61 \%$ in Portugal, from $24 \%$ to $44 \%$ in Italy, from $23 \%$ to $42 \%$ in Greece, and from $20 \%$ to $40 \%$ in Spain. The respective numbers for France, Germany and the Netherlands, lie somewhere between these extremes.

Given that this paper proposes an interpretation for the current pattern of living arrangements based on a delay of marriage, any alternative explanation leading to a delay of marriage could have the same effect on living arrangements in countries with strong family ties. To address this concern, I analyze two alternatives channels by which the desired marriage age could have changed: a worldwide increase in housing prices, and increases in female labor force participation rates. Another potential problem with my identification strategy is of course the existence of unobserved or unobservable home country characteristics that might be correlated with living arrangements, but uncorrelated with culture. I attempt to address this concern by controlling for a variety of factors that are likely to create omitted variable bias such as mother's labor market status, type of family business, level of education, and family income among others.

The rest of the paper is organized as follows. Section II gives an historical perspective on cultural differences in family structures. Section III derives the empirical 
estimation equation and presents the empirical results. Section IV provides further discussion. Section V concludes.

\section{DifFERENCES IN FAMILY STRUCTURES}

Differences in family structures in Western Europe have been extensively studied by Reher (1998). According to the author, at the European level, there are considerable differences in terms of family ties between Northern and Southern European countries. The latter are grouped together as "strong family countries", and contrasted with the “weak family countries” of Northern Europe and of North America (Reher, 1998) ${ }^{7}$. "The strength or weakness refers to cultural patterns of family loyalties, allegiances, and authority but also to demographic patterns of co-residence with adult children and older family members and to organizing support for the latter” (Reher, 1998)

In Northern Europe and in the United States, the cultural norm for young adults is to leave their parent's place before marriage, in Mediterranean Europe only for marriage. These divergent practices appear to have deep historical roots. From at least the Middle Ages until the beginning of the nineteen century, it was common for young adults in England to leave the parental households for a prolonged period before marriage. There is also important evidence of a similar practice in Northern Europe (Mitterauer and Sieder (1977). ${ }^{8}$ English and Northern European marriage customs contrasted with those in Mediterranean Europe, where leaving home before marriage was unacceptable and meant that the ties to the parental household were severed. This practice seems to go much more back in time: in Southern Europe was the Muslims tradition that emphasized kinship and the vertical relationship between generations; while in the North, Germanic tradition and

\footnotetext{
${ }^{7}$ The 'weak'-'strong' dichotomy is associated to a North-South gradient, with the Scandinavian countries generally having the weakest family ties, the Mediterranean countries the "strongest" and the other continental countries lying somewhere in between. The distinction between "strong" and "weak" family ties also does not include countries of Eastern Europe, which have a completely different system in terms of marriage regimes, demographic structures and family systems (Hajnal, 1965).

${ }^{8}$ Reher attributes this pattern to the large number of servants in Northern Europe and England. Data taken from numerous local studies shows that before the mid-nineteenth century servants were generally between two and four times more numerous in Northern European societies than in Southern Europe. On the whole, between 50 and 80 percent of young people spent some of their young lives as servants before marriage in weak-families areas of Europe, as opposed to 15-30 percent in strong-family areas of the south. For most people in Southern Europe, then, the permanent departure of young adults from home came only with marriage, as opposed to the practice in England or Northern Europe where marriage took place after several years away from home.
} 
the Reformation contributed to the development of a "weak" family. Differences between ethnic groups in such patterns have also appeared in other historical contexts. In her study of the family in New York State during the 1920's, Weiler (1986) found that: “The immigrants from Southern Europe stressed the value of children as insurance in old age, whereas Americans and Western Europeans valued individualism and independence between generations".

These differences in marriage customs between regions of Europe, related to the strength of family ties between generations, never disappeared and are part of the cultural heritage of those countries. What changed between the past and today is a substantial delay in marriage for the Southern European group. An interpretation of this peculiar pattern has been given by Bettio and Villa (1998). Those authors present a theory where a change in the attitude between parents and children has favored an alternative model of "emancipation" of family members (where in sociological jargon emancipation literally means freeing oneself from parental control) within the family rather than from the family (as in Northern Europe) only in Mediterranean Europe. Similarly, Dalla Zuanna (2001) draws on the notion of the strong family system to explain the Southern European evolution of living arrangements. He argues that a strong family system is still persistent in Southern Europe, as most people consider their own utility and family utility to be the same. Familism and the new freedom enjoyed by the youth encourage late departure from the parental family. This hypothesis is explored in this paper.

\section{II.A. Youth living with their parents: the Italian case}

This section presents some empirical evidence supporting the hypothesis that the increased autonomy of children enjoyed at their parents place plays indeed an important role in determining living arrangements.

I use a telephone survey from the Institute for Population Research in Italy. ${ }^{9}$ This survey is a study of behavior of Italian youth with a focus on the causes of prolonged stay at the parental home and youth aspiration and perception of work. The survey, conducted in 1998, consists of a sample of 4500 youth, 20-34 year olds, still living with their

\footnotetext{
${ }^{9}$ Evidence on Italians is not representative of patterns in other countries; however it is the only behavioral survey available. Lack of such a type of surveys for other countries is indeed not surprising; given that the phenomenon of "staying at home" is unknown in Scandinavian Europe, there is no reason for those countries to study it.
} 
parents ${ }^{10}$. It classifies young adults into four different categories, employed (full and parttime), unemployed, seeking for first job and students. I shall omit students from the analysis because in Italy student mobility is low. Students usually live with their family at least until they complete college.

The survey collects information on a wide variety of family issues including labor force participation status, freedom, rules and participation in family life, reasons, conditions, advantages and disadvantages of leaving home as well as standard individual demographic characteristics. It also poses a series of questions to young interviewees to evaluate their autonomy and the material circumstances within the family. Questions concern whether children could "invite friends home without asking permission”; whether "they would be having any problem about coming home whenever they liked", "spending the night away from home without letting their parents know", "inviting friends home when their parents were away”.

I shall test to see whether freedom inside the household is a reason for why young adults remain in their parents' home. I define a dummy variable called “freedom” equal to 1 if children answer yes to the questions concerning the possibility of inviting friend home without permission and spending the night away without letting their parents know. I use this variable as a proxy for children autonomy in their parents' home. It should increase the desire to stay at home. Interviewees were also asked if they had a serious love relationship for more than three years; I use the answer to this question to construct a dummy which proxies how close children are to marriage (in Italy youth move out of their parents' place only to get married and not to cohabit).

The dependent variables used in my regression is the "desire to stay at home" of working-age individuals currently living with their parents. Each young adult living with his/her parents between age 20-34 was asked whether he/she wishes to leave the parental place or not in the next 12 months.

\footnotetext{
${ }^{10}$ Unfortunately the survey is conducted only among youth living at home, which is not ideal. However in this age group, they constitute $82 \%$ of the population and the results can still be considered indicative of their attitudes towards being stay-at-homes.
} 
Table I estimates the basic linear probability model for the desire to stay home ${ }^{11}$; the regression controls for a quadratic in age, area dummies, a female dummy, household size, and a variable indicating the demographic density of the place in which young adults live.

\section{[Insert Table I]}

The "freedom" variable has a positive sign and is significant at the 1 percent level: Those living in more liberal families have a higher probability of remaining with their parents; the effect of being close to marriage is negative and significant at the one percent level, as expected. In the South, because of the more traditional confines of the home, young adults are more likely to leave their parents' place. However, if young adults were staying at home only as a result of economic necessity (due to high unemployment rate), we would not necessarily expect a negative coefficient on the South dummy. After all, those are the ones who should be more inclined to stay home because the outside conditions are extremely unfavorable to them (in this area the unemployment rate for youth is twice as large as in the rest of Italy).

\section{III.EMPIRICAL ANALYSIS}

I argued that unfavorable economic conditions could only partly explain the high propensity of young Southern Europeans to live with their parents. The goal of this empirical section is to disentangle how the sexual revolution interacted with the two different family types in determining living arrangements. To identify the role of the two family structures one could look at the differential evolution of living arrangements across countries where the sexual revolution had a different impact. Such an approach fails to disentangle cultural factors from economic factors, since both are combined in a "country effect.” To get around this problem and isolate the impact of family types, I look at the living arrangements of second-generation European immigrants in the US at two different points in time: in 1970, the period prior to the sexual revolution, and in the late 1990's, after the sexual revolution had taken place. By doing this I can observe young adults of different national origins in a virtually identical economic environment. The extent to

\footnotetext{
${ }^{11}$ Marginal effects for probit estimation have been also calculated as a consistency checks. The magnitude and significance of the coefficients remain the same.
} 
which those from immigrant families differ from natives and from each other might constitute a measure of the importance of cultural differences in shaping living arrangements. According to my explanation, Southern European countries in the period preceding the sexual revolution should have had a proportion of young adults living at home similar to that of other European countries. In contrast, in the 1990's this share should have grown much more for Southern European immigrants than for immigrants from other countries. As for the other groups of second-generation European immigrants, one should not observe substantial variation over time in their living arrangements, consistent with the behavior of their European counterparts.

By studying the behavior of second generation immigrants in the US, I can isolate the impact of economic conditions since all of them face the same labor market institutions, housing market and welfare state (as long as state fixed effects are able to control for these variables). Focusing on second-generation immigrants also has the advantage of reducing selection problems, since they are born and raised in the USA. Given that the immigration-selection bias works against finding a cultural effect (people who left their countries of origin are the one who broke up family ties), the finding of differences in living arrangements by place of origin can be attributed to cultural effects.

\section{III.A. Data and Summary Statistics}

To identify the effects of the interaction of family types and decreased stigma regarding sexual relations, I focus on second-generation immigrants in the US between 18 and 33 years old, comparing two different periods of time: before (1970) and after (2000) the sexual revolution.

I implement my empirical analysis using data from the 1970 United States Census and from pooled 1994-2000 March Current Population surveys (CPS). The 1970 United States Census five-percent sample collected information on parent's place of birth. ${ }^{12}$ After 1994, the March Current Population Survey includes questions on the place of birth of each individual and his or her parents. Because of the relatively small number of observations in the CPS (compared to the Census), I pool the March CPS from 1994 to 2000. I restrict the definition of "second-generation" to native-born individuals with

\footnotetext{
${ }^{12}$. Unfortunately this information is not present in the most recent Census datasets
} 
immigrant fathers (this requirement substantially expands the second-generation group relative to the alternative of requiring two immigrant parents). ${ }^{13}$

Table II shows the living arrangements of several groups of second-generation immigrants for the age group of 18-33 years old in both periods. Several factors should be noted in Table II. First, during the 1970's the fraction of youth living with their parents was slightly larger among immigrants from Southern European countries, but by a small margin; in contrast, in the late 1990's this fraction increased dramatically among immigrants from Greece (from 23\% to 49\%), Italy (from 24\% to 44\%), Portugal (from $25 \%$ to $61 \%$ ) and Spain (from $20 \%$ to $34 \%$ ), remained almost constant for the US, the UK and the Scandinavian countries, with the other continental countries (France, Germany and Netherlands) lying somewhere in between ${ }^{14}$.

\section{[Insert Table II]}

The table thus shows that regardless of common economic conditions, there is a significant difference between the behavior of Southern and Northern European descendants and the other immigrants.

Figure I plots the correlation between the change over time in the fractions of stayat-homes in their original countries and among immigrants. This correspondence suggests that there must be some cause other than poor economic conditions for staying with parents that varies by country. If poor employment possibilities are the sole cause for staying at home, the behavior of Mediterranean descendants in the United States should not be so distinctive. In addition, this high correlation suggests that living arrangements among immigrants mirror the changes over time in the country of origin, an indication that a common pan-Atlantic shock (such as the sexual revolution) affected the strong and weak family types in a different way.

\section{[Insert Figure I]}

\footnotetext{
${ }^{13}$. Defining "second generation" immigrants according to the country of origin of the father is standard in literature (see Card, DiNardo and Estes, 1998). The fraction of people living with their parents has been calculated also when both parents have the same ethnicity (results available from the author). This strengthens the role of family structure, with higher/lower sample means for strong/weak family systems. I do not use this alternative definition of second generation, since it reduces substantially the number of observations.

${ }^{14}$ Among those countries, only for France, which maybe the exception because it is also partly Mediterranean, was the increase as large as 15 percent, from $17 \%$ to $32 \%$.
} 


\section{III.B. Statistical Results}

The primary source of identification in this empirical section consists of comparing living arrangements among 18-33 years old individuals who live with their parents relative to those who do not, paying attention to the effects of country of origin on the probability of staying at home. The linear probability model I estimate is:

$$
s_{i}=\alpha+\sum_{k} \beta_{k} M_{i k}+\delta X_{i}+\varepsilon_{i}
$$

where

$s_{i}$ equals to one if the young adult lives with her/his parents and is zero otherwise.

$M_{i k}$ is equal to one if $i$ belongs to immigrant group $k$ and is zero otherwise,

and $X_{i}$ is a set of control variables, to be described later.

In this model the parameter $\beta_{k}$ is regarded as country-specific cultural effect, since the excluded group is given by the natives. A significant coefficient of .13 for the ethnicity $k$ for example means that compared too natives, $13 \%$ more immigrants belonging to the ethnicity $k$ stay at home with their parents in the US.

Focusing only on 18-33 year olds, I estimate my basic staying at home regression in Table IIIA (for 2000) and Table IIIB (1970), where I report the coefficients of the basic OLS regression ${ }^{15}$ of the children variable on the father's country of origin dummies, and the associated robust standard errors. I include dummies for Italy, Spain, Portugal, Greece, France, Germany, Netherlands, Ireland, Poland, UK and Scandinavian Europe. Native-born Americans are the excluded group. I report the results for four different specifications (models 1 to 4). Model 1 controls only for demographic characteristics (a quadratic in age, state dummies ${ }^{16}$ and 2 metro indicators), model 2 includes education variables, model 3 includes labor-market-status variables, finally the last specification controls also for per-capita family income, defined as total family income divided by the number of family components. ${ }^{17}$

\section{[Insert Tables IIIA and IIIB]}

\footnotetext{
15 Marginal effects for probit estimation have been also calculated as a consistency checks. The magnitude and significance of the coefficients remain the same.

16 State fixed effects should control for local geographic variation in labor market and institutions.

17 For the CPS datasets I converted the reported income information from the seven samples into constant1995 dollars, prior to pooling the data.
} 
Results in Table IIIA suggest that in the late 1990's, after controlling for several characteristics, the probability of living at home is higher for those of Southern European origin. The estimated $\beta_{k}$ coefficients are individually positive and significant at the $1 \%$ level for all the Southern European countries, except Spain (there are few number of observation for the Spanish group), indicating significant evidence for a "cultural effect" on living arrangements. The similar regression for the earlier period (Table IIIB) gives different results; in this case the probability of living with parents is close to constant across ethnicity and only slightly higher for Southern European descendants.

An alternative way of testing whether culture is an important determinant for living arrangements for second-generation immigrants in the USA is to include in the regression, instead of country dummies, the fraction of 18-33 year olds living with their parents in the European countries of origin. This variable summarizes the cultural norm of the country of origin: it should capture the impact of the country of origin cultural environment on immigrant preferences for family formation. The coefficient on this fraction is an indication on how living arrangements of second-generation immigrants tend to replicate the family arrangements (cultural norm) of their European countries of origin. While the regression with dummies captures whether Mediterranean immigrants are more likely to stay at home (compared to the natives), the regression with the cultural norm allows us to capture synthetically the importance of culture as supposed to other explanations. A positive and significant coefficient is anticipated in both regressions (both in the 1970’s and 2000 culture should matter for living arrangements).

I estimate the following model:

$$
s_{i j k}=\alpha+\beta C_{k}+\delta X_{i}+\varepsilon_{i j k}
$$

where $s_{i j k}$ is the decision of staying at home for a young adult $i$ who lives in state $j$ and is of cultural origin $k . C_{k}$ is the proxy for the cultural origin variable, specifically it represents the fraction of people living with their parents in the original countries. $X_{i}$ is a set of controls, including age, sex, education, labor market status and metropolitan dummies. The regression controls for a full set of dummies for the states of residence. All the standard errors are corrected for clustering at the country of origin level. 
The results for this regression are reported in Tables IVA (for 2000) and IVB (for the 1970's). Also with this alternative specification the cultural norm is statistically significant at the $1 \%$ level in both periods. In 2000, a one standard deviation increase in the cultural norm correspond to a $16 \%$ increase in the fraction of people staying at home (as a comparison, in the same period a one standard deviation increase in the unemployed dummy correspond only to a $6 \%$ increase in the fraction of people staying at home). As for the 1970's, a one standard deviation increase in the cultural norm correspond to a $3 \%$ increase in the fraction of people staying at home (a one standard deviation increase in the unemployed dummy correspond to a $4 \%$ increase in the fraction of people staying at home).

\section{[Insert Tables IVA and IVB]}

In order to test for a "structural shift" in living arrangements, possibly caused by the sexual revolution, I also run a pooled regression (including both CPS and Census data) in which I include the same variables of the original model and the interaction terms of the ethnicity dummies with a year 2000 dummy $^{18}$. Besides controlling for state dummies, which should take care of state fixed effects on the decision to live at home, this regression also controls for state-specific time variations (including an interaction of the state dummies with the year 2000 dummy). This should rule out the possibility that statespecific trends in areas in which immigrants concentrate are driving the results (a more pronounced increase in housing prices or a change in the welfare system in those states in which Mediterranean immigrants concentrate could have been responsible for the pattern observed in the US). I run the following regression:

$$
s_{i}=\alpha+\sum_{k} \beta_{k} M_{i k}+\sum_{k} \gamma_{k} M_{i k} I_{2000}+\delta X_{i}+\varepsilon_{i}
$$

The interaction of the ethnicity dummies and the year 2000 dummy can be regarded as a measure of a structural change in living arrangements across cultures. If the values of the coefficient on the interaction terms, $\gamma_{k}$, are significantly different from zero, I shall claim to have identified a structural shift in living arrangements between 1970 and 2000. The coefficients on the interaction terms, $\gamma_{k}$, are all positive (see Table V); based on the $\chi^{2}$, the $\gamma_{k}$ are jointly different from zero at the 1 percent level of significance for

18 A dummy equal to one for the years 1994-2000 in the CPS dataset. 
Southern Europe but not jointly significant for France, Germany, Ireland, Netherlands, Poland, Scandinavian Europe or the UK.

\section{[Insert Table V]}

\section{III.C. Social acceptability of living at home}

In this section I explore the role of the neighborhood composition in the determination of living arrangements. Living at home in Mediterranean Europe is socially accepted: the probability of staying at home is higher the greater is the proportion of young adults behaving similarly in the same age group. In the USA as well the probability of replicating the cultural norm of the country of origin should be higher the greater the density of their own ethnic group in a certain neighborhood (second generation Italians who live near other second generation Italians- e.g. in Little Italy in New York- should be more likely to reflect the behavior of their country of origin than those who do not-for example those in Alabama). If peer effects are important, then a Southern European young adult should be more likely to stay at home in those PMSA with a higher concentration of Southern European immigrants. I should not observe a similar correlation among other second-generation European immigrants, for whom the norm is not living at home.

I find a systematic relation between large increases in the stay-at-home rates of $2^{\text {nd }}$ generation Southern Europeans from 1970-2000 and higher concentrations of $2^{\text {nd }}$ generation Southern Europeans at the PMSA level ${ }^{19}$. I do not observe the same phenomenon for Western (France, Germany and the Netherlands) and Northern Europeans (Scandinavian Europe and the UK) ${ }^{20}$. Those correlations are reported in Figures II, III and IV in Appendix 2.

\section{DISCUSSION}

In this section I try to explore the robustness of my findings. This paper proposes an interpretation based on a delay of marriage due to a change in attitudes towards sexual behavior, which implies a longer time spent at one's parents place in countries with strong

\footnotetext{
19 I define concentration as the number of second-generation immigrants, 18-33 years old, living in a given state divided by the state population of the same age group.

${ }^{20}$ To confirm that the analysis is not just picking up secular differences across states, I also found that the stay-at-home rates for U.S. natives do not covary with the concentrations of Southern Europeans. This exercise allows me to conclude that differences in living arrangements are most likely driven by ethnicity and not by economical characteristics of the areas in which different immigrant groups live.
} 
family ties. Anything that leads to a delay of marriage, however, could have the same effect on living arrangements in countries with strong family ties. To address this concern, I analyze two possible important alternatives that could have changed the desired age of marriage: a worldwide increase in housing prices and in female labor force participation.

Another issue to consider is that there may be other important country of origin characteristics, left out of the analysis, that are correlated with living arrangements and uncorrelated with culture. To address this concern, I explore the role of mother's housework and of father's occupation and father's age.

Increase in housing prices. "Staying-home" behavior could be caused by an increase in housing prices all over the world, coupled with different preferences in home ownership across cultures. If, for example, Southern Europeans both in the US and in Southern Europe have a higher preference for owning the house they live in, an increase in house prices all over the world could have been responsible for the increase in the fraction of young adults living at home: Southern Europeans in the US and at home would have to wait longer to leave their parental house before buying their own place. To rule out this possibility I look at the rate of home ownership across ethnicities in 2000. If Southern Europeans tend to stay with their parents because of different preferences for home ownership, we should observe a higher fraction of home ownership among this immigrant group, after controlling for individual characteristics (sex, age, education, labor market status, family income and metropolitan areas dummies), state dummies and years of immigration dummies. The results for the home ownership regression are reported in Table A3. There is no evidence of differences in preferences for home ownership across ethnicities, therefore we can rule out the possibility that living arrangement increased as a response to a rise in housing prices.

Increase in female labor participation. An alternative possibility to explain the pattern in living arrangements in Western Europe is the increase in female labor participation; women today could tend to delay marriage more than in the 1970s due to a higher participation in the labor market. The cultural differential effects could come into play in this case because a working woman may want to delay marriage and child bearing and "has" to live at home in certain cultures but not in others. 
To test this hypothesis, I regress the probability of living at home on a female dummy, Southern Europe, Western Europe and Northern Europe dummies and an interaction between Southern, Western and Northern Europe with the female dummy. If this hypothesis were true, we should expect a positive coefficient on the female dummy, and a positive coefficient on the interaction term between female dummy and Southern dummy in 2000, but not in the 1970s. The results of this regression are reported in Table A4. It is apparent from this table that the female dummy is negative and significant in both 1970s and 2000. This would be consistent with the story that normally parents tend to be more strict with girls than with boys and that women tend to get married earlier compared to men. The interaction term between Southern Europe and female dummy is not significant in 2000, and positive and significant at the 5\% level, but small, in the 1970's. If an increase in labor participation was causing the phenomenon, we should observe exactly the opposite pattern: a higher propensity to leave their parents place today among the Southern European women, due to increased female labor participation, compared to the old days.

The role of mother's housework. The presence of mother at home has been taken as an important reason for why children do not move out. The theoretical model of Diaz and Guillo [2000] stresses the mother's housework as a public good, which induces young adults to stay home. According to Diaz and Guillo, Southern Europeans are living at home because in Mediterranean Europe, female labor participation is very low. We should then observe a correlation between mothers' labor status and living arrangements. I look at the differences in female labor participation among immigrant groups in 2000 and I do not find any systematic relationship between those two variables. Table A5 reports the labor market status of the mothers of young adults staying at home. For Southern Europe the fraction of mothers employed goes from $55.38 \%$ for Italy to $81.29 \%$ for Portugal (Portugal has the highest fraction of young adults living at home among Southern European countries, so we should observe a lower percentage of employed women if Diaz-Guillo's hypothesis is correct). As for the other immigrants living at home, for the group including Western Europe, Ireland and Poland, the fraction of employed mothers goes from $41.26 \%-N e t h e r l a n d s$, to $100 \%$-France- (also in this group there is no systematic relationship between mother's occupation and living arrangements; France, for 
example, has the highest fraction of mothers employed and the highest fraction of children living at home.) Note that the number of observations regarding mothers' labor market status is extremely small for some ethnicities (only 14 for Netherlands and 13 for France). This is due to the fact that there is a much smaller number of observations when we define second generation looking at the country of origin of the mother; this number decreases even more when we look at their labor force status, since a lot of them do not report this information.

Fathers' occupation and parents' age. Another possible alternative interpretation for the long stay of young adults at home is that immigrants have particular occupations, such as family oriented business, which requires the presence of children at home. In Table A5, for each immigrant group I look at the three major (in percentage terms) occupations and the three major types of industry in which fathers of children staying at home are working. Southern European fathers are not disproportionately involved or are not disproportionably working in industries that are associated with a higher fraction of children staying at home.

This analysis is only descriptive; I cannot include in the regression variables relative to mother labor status, type of occupation of heads of family and parents' education because this information is not available for young adults living out of their parents' place.

\section{V.CONCLUSION}

Over the last 25 years the family structure has changed substantially in Southern Europe. Mediterranean youth tend to stay at home for a very long time, postponing later stages of adult life, such as getting married and having children. It is important to understand why these changes in family structure have occurred. Several stylized facts suggest that the economic explanations given so far are not sufficient to interpret the phenomenon. There is, in consequence, need for another hypothesis. This paper proposes a cultural interpretation for the dramatic increase in the faction of stay-at-homes in Mediterranean Europe. I argue that the sexual revolution of the 1970s - by liberalizing parental attitudes - had a differential impact on living arrangements in Northern and Southern Europe on account of the closer parent-child ties in Southern Europe. For Mediterranean youth, for whom the social norm is to live with their parents until marriage, 
the new liberal parenting attitudes towards sexual behavior implied a reduction in the privacy cost of living at home, with a consequent postponement in marriage. For Northern European youth, used to leave their parents’ home at a young age regardless of marriage, it implied different forms of living arrangements such as cohabitation.

I disentangle economic from cultural effects by comparing family attitudes of immigrants of different nationality living in an identical economic environment, the US, before and after the sexual revolution. There is a striking correlation between the fraction of second generation immigrants who live with their parents in the US and the corresponding fractions in the countries of origin. Moreover the immigrant group specific changes in the stay-at-home rates from 1970 to the 1990 also mimic those in Europe. The duplication over time of the European patterns among $2^{\text {nd }}$ generation immigrants in the U.S. provides credible evidence that cultural norms and an exogenous shock- such as the sexual revolution- could play a significant role in the living arrangements of young adults.

Leaving home is a phenomenon that is well-worth studying. The dramatic changes in living arrangements over the last 30 years have can have major macroeconomic and demographic consequences. In Southern Europe young people leave home when they get married. The household formation and procreation is postponed with potential important effects on the decline in fertility for these countries ${ }^{21}$. Understanding the reasons behind such a dramatic change in family structure are then quite relevant for the debate on policies attempting to increase employment and fertility among younger European cohorts and the discussion surrounding the solvency of intergenerational transfer programs in Mediterranean countries.

\footnotetext{
${ }^{21}$ Mediterranean Europe has a very low incidence of out-of-wedlock births (3\% in Greece, 8\% in Italy as opposed to $55 \%$ in Sweden)
} 


\section{REFERENCES}

Akerlof, George A., Janet L. Yellen, and Michael L. Katz, "An Analysis of Out-ofWedlock Childbearing in the United States”, Quarterly Journal of Economics, CXI (1996), 277-317.

Bentolila, Samuel, and Andrea Ichino, “Unemployment and Consumption: Are Job Losses Less Painful Near the Mediterranean?” IUE, July 2001, mimeo.

Becker, Sasha O., Samuel Bentolila, Ana Fernandes, and Andrea Ichino, "Parental Job Insecurity and Children's Emancipation: The Italian Puzzle”, IUE, July 2002, mimeo.

Bettio, F. and P. Villa, "A Mediterranean Perspective on the Breakdown between Participation and Fertility”, 1998, Cambridge Journal of Economics, 22, 137-171

Card, David, DiNardo John and Eugena Estes, “The More Things Change: Immigrants and the Children of Immigrants in the 1940s, the 1970s, the 1990s”, NBER Working Paper 6519, April 1998.

Carroll, Christopher D., Byung-Kun Rhee, and Changyong Rhee, "Are There Cultural Effects on Saving? Some Cross-Sectional Evidence," Quarterly Journal of Economics, CIX (1994), 685-699.

Dalla Zuanna, G., “The Banquet of Aeolus: A Familistic interpretation of Italy’s lowest low fertility”, 2001, Demographic Research 4 (5)

David H. P. eds (1999), From Abortion to Contraception, London: Greenwood Press.

Diaz, Antonia and Maria Dolores Guillo, "Family Ties and Unemployment”, Instituto Valenciano de Investigaciones Economicas, Working Paper WP-AD 2000-07, March 2000.

Fernandez, R. and A. Fogli, "Culture: An Empirical Investigation of Beliefs, Work and Fertility”, 2005, NBER Working Paper 11268.

Fogli, Alessandra, "Endogenous Market Rigidities and Family Ties”, New York University, September 2000, mimeo.

Galland, Olivier, "Precarietà e Modi di Entrata nella Vita Adulta”, in Eta' e Corso della Vita, Saraceno Claudia, eds. (Bologna: Il Mulino, 1986). 
Ghidoni, Michele, “Determinants of Young Europeans’ Decisions to Leave Parental Household”, University College of London, February 2001, mimeo.

Giannelli, Gianna Claudia, and Chiara Monfardini “Joint Decisions on Household Membership and Human Capital Accumulation of Youths: The Role of Expected Earnings and Labor Market Rationing”, Journal of Population Economics, XVI (2003), 265-285.

Haijnal, J. (1965) “European Marriage Patterns in Perspective”, in D.V. Glass, D.E.C. Eversley, eds., Population in History. London, 101-143.

Goldin, Claudia, and Lawrence F. Katz, “Career and Marriage in the Age of the Pill”, American Economic Review, XC (2000), 461-465.

-----, “The Power of the Pill: Oral Contraceptives and Women's Career and Marriage Decisions”, Journal of Political Economy, CX (2002), 730-770.

Kiernan, K., "Leaving Home: Living Arrangements of Young People in Six WestEuropean Countries”, European Journal of Population 2: 177-184

Livi Bacci, Massimo, Abbondanza e Scarsità. Le Popolazioni d'Italia e d'Europa al Passaggio del Millennio (Bologna: Il Mulino, 1997).

Manacorda, Marco, and Enrico Moretti, “Intergenerational Transfers and Household Structure: Why Do Most Italian Youths Live with their Parents?”, London School of Economics, January 2002, mimeo.

Martinez-Granado, Maite, and Javier Ruiz-Castillo, “The Decisions of Spanish Youth: A Cross-Section Study”, Journal of Population Economics, XV (2002), 305-330.

Mitterauer, M. and R. Sieder, The European Family: Patriarchy to Partnership from the Middle Ages to the Present, Chicago: University of Chicago Press, 1977.

Neyer, G.R., “Family Policies and Low Fertility in Western Europe”, MPIDR WP 2003021. Max Planck Institute for Demographic Research.

Pooley, Colin, and Jean Turnbull, “Leaving Home: The Experience of Migration from the Parental Household in Britain since c. 1770”, Journal of Family History, XXII (1997), 290-424.

Reher, David Sven, “Family Ties in Western Europe: Persistent Contrasts”, Population and Development Review, XXIV (1998), 203-234. 
Rydell (2003), "Demographic Patterns from the 1960s in France, Italy, Spain and Portugal. A Review” Institute for Futures Studies 2003:2

Weiler, Sue N., "Family Security or Social Security? The Family and the Elderly in New York State during the 1920s”, Journal of Family History, XI (1986), 77-96. 


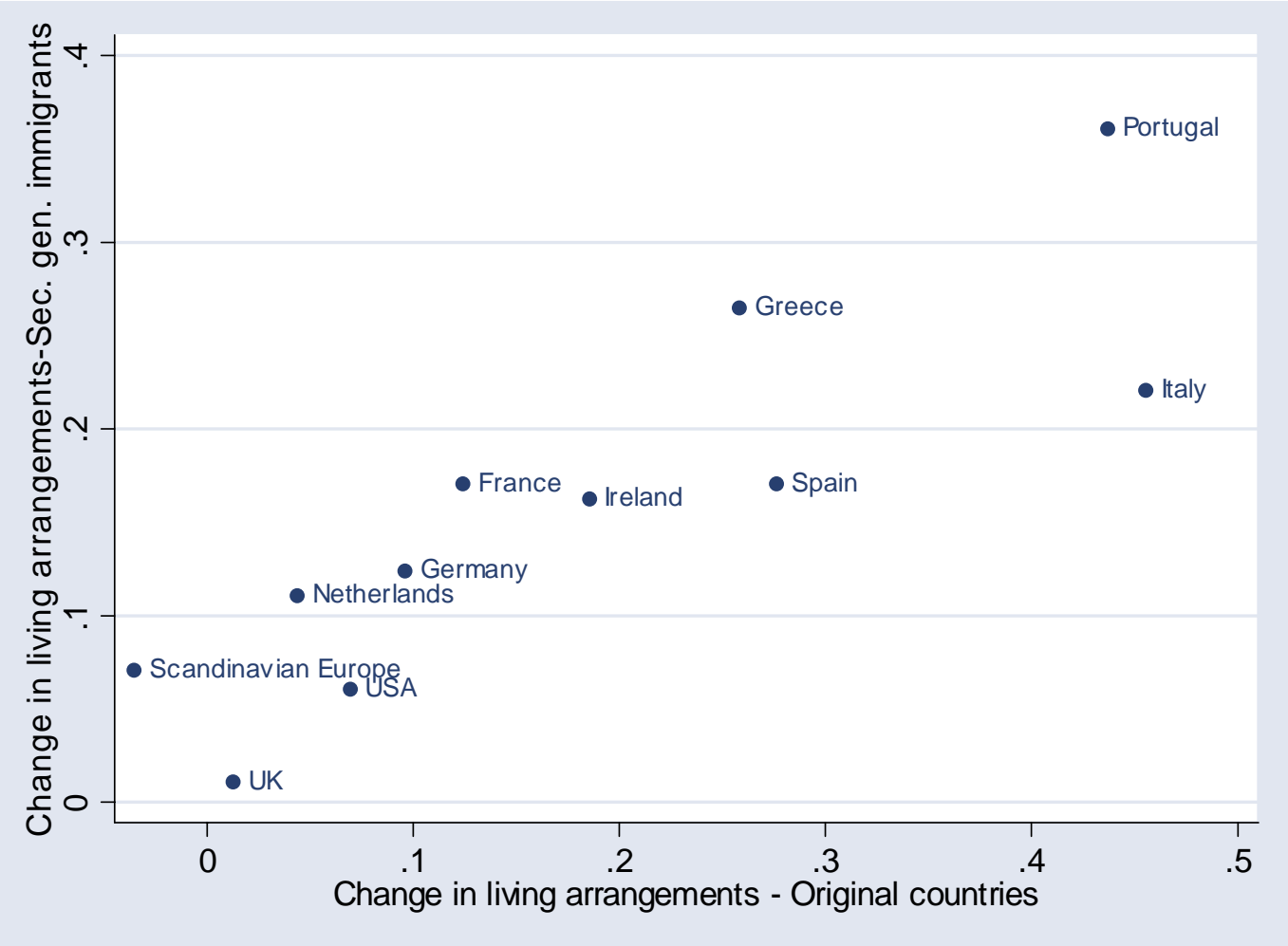

FIGURE I

The Change in the Fraction of "Stay-at-Homes" (18-30-Year-Olds) The Correlation between Immigrants and their European Counterparts 


\section{TABLE I}

AtTitudes toward PERMANENCE AT Home

\section{LINEAR PROBABILITY MODEL}

DEPENDENT VARIABLE: “DESIRE TO STAY WITH PARENTS” DUMMY

Close to get married

$-.0745^{* * *}$

Freedom

(.0155)

$.0482 * * *$

(.0198)

North

.0121

South

$-.0544 * * *$

Age

$-.0504 * * *$

(.0225)

Age squared

$.0006^{* *}$

College completed

(.0005)

Household size $-.1844 * * *$

(.0309)

$-.0082$

(.0078)

Demographic size $-.0132 * * *$

(.0043)

Female

.02562*

(.0158)

Constant

1.6898

(.3406)

Survey “Giovani che non lasciano il nido”, Institute for Population Research, Italy, author's calculation

Sample size: 3126

The sample includes people 20-34 years old, excluding students

$* * *=1 \%$ significance level

$* *=5 \%$ significance level

$* *=10 \%$ significance level 
TABLE II

Young ADULTS LIVING WiTH THEIR PARENTS, 18- TO 33-YEAR-OLDS, SECOND-GENERATION IMMIGRANTS*

\begin{tabular}{|c|c|c|c|c|}
\hline Sample & \multicolumn{2}{|c|}{ Census 1970} & \multicolumn{2}{|c|}{ CPS 1994-2000 } \\
\hline & Mean & $\begin{array}{l}\text { Standard } \\
\text { Deviation }\end{array}$ & Mean & $\begin{array}{c}\text { Standard } \\
\text { Deviation }\end{array}$ \\
\hline \multicolumn{5}{|l|}{ Variable } \\
\hline Entire sample & 2310 & .4214 & .2768 & .4474 \\
\hline Portugal & .2525 & .4355 & 6099 & .4889 \\
\hline Greece & .2337 & .4237 & .4901 & .5010 \\
\hline Italy & .2414 & .4280 & .4413 & .4979 \\
\hline Spain & 2047 & .4050 & 3410 & .4785 \\
\hline Ireland & .2346 & .4240 & .3383 & .4783 \\
\hline Poland & .2652 & .4416 & 3231 & .4692 \\
\hline France & .1773 & .3832 & 3267 & .4722 \\
\hline Germany & .1739 & .3791 & .2864 & .4526 \\
\hline Netherlands & .2145 & .4114 & 3095 & .4668 \\
\hline $\begin{array}{l}\text { Scandinavian } \\
\text { Europe** }\end{array}$ & 1501 & .3574 & .1857 & .3918 \\
\hline UK & .2175 & .4127 & .2267 & .4195 \\
\hline USA & .2313 & .4216 & .2753 & .4467 \\
\hline Sample size & \multicolumn{2}{|c|}{393,141} & \multicolumn{2}{|c|}{163,076} \\
\hline
\end{tabular}

*The fraction of youth living at home is calculated by ethnicity

** Scandinavian Europe includes Denmark, Finland, Norway and Sweden; 


\section{TABLE IIIA}

YounG ADULTS (18- TO 33-YEAR-OLDS) LIVING WITH THEIR PARENTS, SECOND-GENERATION IMMIGRANTS, CPS 1994-2000

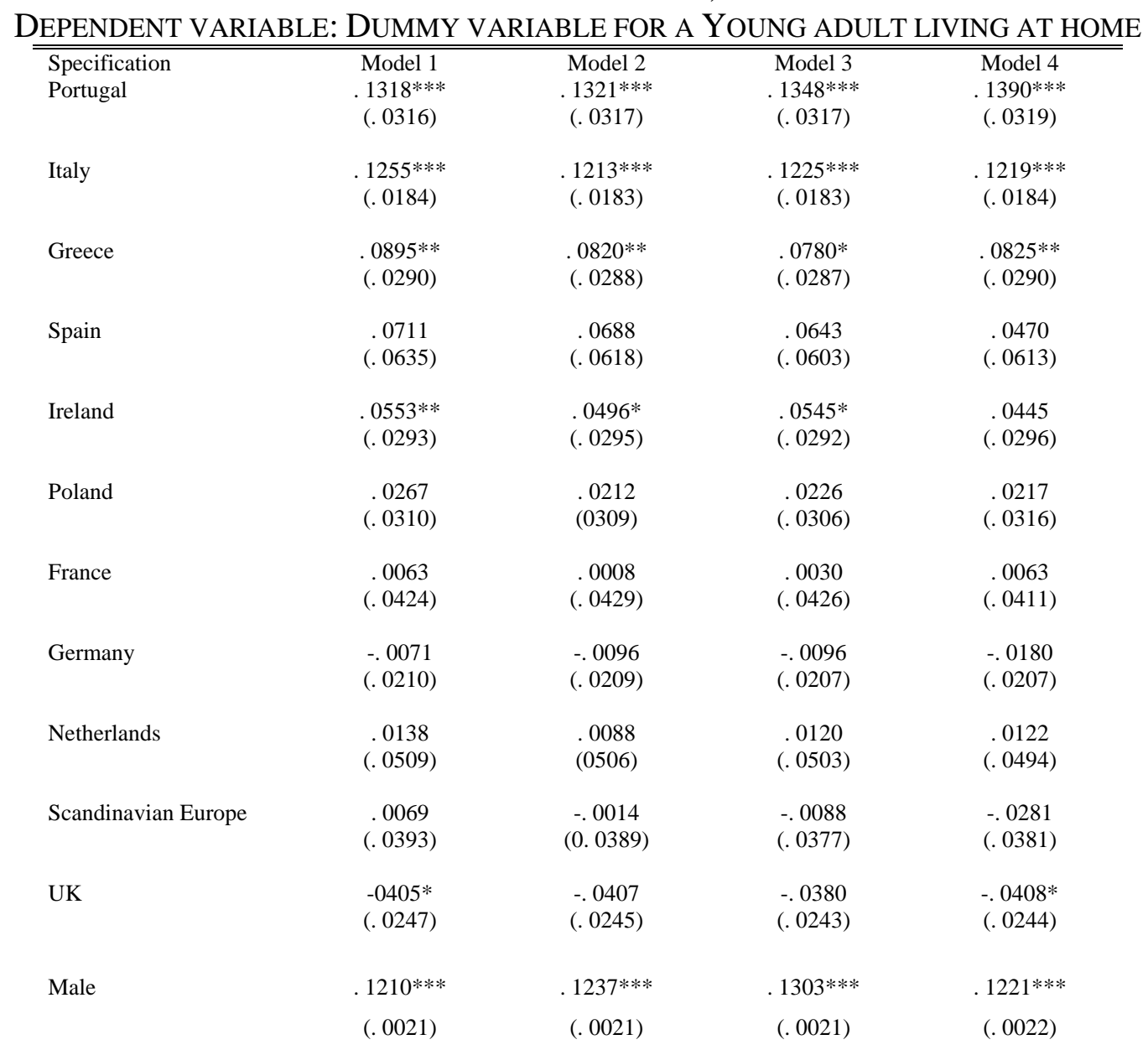

\begin{tabular}{|c|c|c|c|c|}
\hline Education & No & & & \\
\hline \multirow[t]{2}{*}{ Less than B.A. } & & $.0136 * * *$ & -.0058 & $.0472 * * *$ \\
\hline & & $(.0052)$ & $(.0052)$ & $(.0057)$ \\
\hline \multirow[t]{2}{*}{ B.A. } & & $.0156 * * *$ & $.0076^{*}$ & $.0541 * * *$ \\
\hline & & $(.0043)$ & $(.0040)$ & $(.0047)$ \\
\hline Labor-market status & No & No & & \\
\hline Unemployed & & & $\begin{array}{l}.0587 * * * \\
(.0055)\end{array}$ & $\begin{array}{l}.0717^{* * * *} \\
(.0055)\end{array}$ \\
\hline Out of Labor Force & & & $\begin{array}{c}.0664 * * * \\
(.0029)\end{array}$ & $\begin{array}{c}.0788 * * * \\
(.0029)\end{array}$ \\
\hline $\begin{array}{l}\text { Per-capita family } \\
\text { income }\end{array}$ & No & No & No & $\begin{array}{l}.0000 * * * \\
(.0000)\end{array}$ \\
\hline \multicolumn{5}{|c|}{$\begin{array}{l}\text { a. Scandinavian Europe includes Denmark, Finland, Norway and Sweden. } \\
\text { b. Robust standard errors in parentheses. } \\
\text { c. Sample size is } 163076 \text {. } \\
\text { d. Other covariates included in the regressions are } 50 \text { state indicators, } 3 \text { metro indicators (urban, rural and metro), and a } \\
\text { quadratic term for age. } \\
\text { e. Per-capita income is defined as the total family income divided by the number of family members. I convert the } \\
\text { reported family income data from the seven CPS samples from current dollars into constant-1995 dollars prior to pooling } \\
\text { across years. }\end{array}$} \\
\hline
\end{tabular}




\section{TABLE IIIB}

\section{Young Adults (18- TO 33-YEAR-Olds) LIVING WITH THEIR PARENTS, SECOND- GENERATION IMMIGRANTS, 1970 CENSUS}

\section{DEPENDENT VARIABLE: A DUMMY VARIABLE FOR A YOUNG ADULT LIVING AT HOME}

\begin{tabular}{|c|c|c|c|c|}
\hline $\begin{array}{l}\text { Specification } \\
\text { Portugal }\end{array}$ & $\begin{array}{l}\text { Model } 1 \\
.0475^{*} \\
(.0261)\end{array}$ & $\begin{array}{l}\text { Model } 2 \\
.0414^{*} \\
(.0261)\end{array}$ & $\begin{array}{l}\text { Model } 3 \\
.0437^{*} \\
(.0260)\end{array}$ & $\begin{array}{l}\text { Model } 4 \\
.0422^{*} \\
(.0261)\end{array}$ \\
\hline Italy & $\begin{array}{l}.0467 * * * \\
(.0068)\end{array}$ & $\begin{array}{l}.0462 * * * \\
(.0068)\end{array}$ & $\begin{array}{l}.0472 * * * \\
(.0067)\end{array}$ & $\begin{array}{l}.0480 * * * \\
(.0067)\end{array}$ \\
\hline Greece & $\begin{array}{l}.0346^{* *} \\
(.0182)\end{array}$ & $\begin{array}{l}.0404^{* *} \\
(.0182)\end{array}$ & $\begin{array}{l}.0391 * * \\
(.0181)\end{array}$ & $\begin{array}{l}.0402^{* *} \\
(.0181)\end{array}$ \\
\hline Spain & $\begin{array}{l}.0212 \\
(.0319)\end{array}$ & $\begin{array}{l}.0195 \\
(.0320)\end{array}$ & $\begin{array}{l}.0206 \\
(.0320)\end{array}$ & $\begin{array}{l}.0171 \\
(.0319)\end{array}$ \\
\hline Ireland & $\begin{array}{l}.0391 * * \\
(.0130)\end{array}$ & $\begin{array}{l}.0399 * * \\
(.0130)\end{array}$ & $\begin{array}{l}.0402 * * \\
(.0129)\end{array}$ & $\begin{array}{l}.0391 * * \\
(.0128)\end{array}$ \\
\hline Poland & $\begin{array}{l}.0490 * * * \\
(.0111)\end{array}$ & $\begin{array}{l}.0558^{* * *} \\
(.0111)\end{array}$ & $\begin{array}{l}.0575^{* * *} \\
(.0111)\end{array}$ & $\begin{array}{l}.0600 * * * \\
(.0110)\end{array}$ \\
\hline France & $\begin{array}{l}-.0169 \\
(.0294)\end{array}$ & $\begin{array}{l}-.0160 \\
(.0295)\end{array}$ & $\begin{array}{l}-.0134 \\
(.0296)\end{array}$ & $\begin{array}{l}-.0191 \\
(.0295)\end{array}$ \\
\hline Germany & $\begin{array}{l}-.0096 \\
(.0085)\end{array}$ & $\begin{array}{l}-.0061 \\
(.0085)\end{array}$ & $\begin{array}{l}-.0041 \\
(.0084)\end{array}$ & $\begin{array}{l}-.0044 \\
(.0084)\end{array}$ \\
\hline Netherlands & $\begin{array}{l}.0085 \\
(.0226)\end{array}$ & $\begin{array}{l}.0090 \\
(.0226)\end{array}$ & $\begin{array}{l}.0076 \\
(.0227)\end{array}$ & $\begin{array}{l}.0056 \\
(.0225)\end{array}$ \\
\hline Scandinavian Europe & $\begin{array}{l}-.0008 \\
(.0102)\end{array}$ & $\begin{array}{l}.0010 \\
(.0102)\end{array}$ & $\begin{array}{l}.0016 \\
(.0102)\end{array}$ & $\begin{array}{l}.0031 \\
(.0102)\end{array}$ \\
\hline UK & $\begin{array}{l}.0170^{* *} \\
(.0102)\end{array}$ & $\begin{array}{l}.0210^{* *} \\
(.0102)\end{array}$ & $\begin{array}{l}.0209 * * \\
(.0102)\end{array}$ & $\begin{array}{l}.0205^{* *} \\
(.0102)\end{array}$ \\
\hline Male & $\begin{array}{l}.0557 * * * \\
(.0011)\end{array}$ & $\begin{array}{l}.0586 * * * \\
(.0012)\end{array}$ & $\begin{array}{l}.0460 * * * \\
(.0014)\end{array}$ & $\begin{array}{l}.0431^{* * *} \\
(.0013)\end{array}$ \\
\hline Education & No & & & \\
\hline Up to $12^{\text {th }}$ grade & & $\begin{array}{l}.0526^{* * *} \\
(.0027)\end{array}$ & $\begin{array}{l}.0513^{* * *} \\
(.0028)\end{array}$ & $\begin{array}{l}.0514 * * * \\
(.0027)\end{array}$ \\
\hline $\begin{array}{l}\text { Some college (from one } \\
\text { to five years) }\end{array}$ & & $\begin{array}{l}.0212^{* * *} \\
(.0028)\end{array}$ & $\begin{array}{l}.0225^{* * *} \\
(.0028)\end{array}$ & $\begin{array}{l}.0205^{* * *} \\
(.0028)\end{array}$ \\
\hline $\begin{array}{l}\text { Labor-market status } \\
\text { Unemployed }\end{array}$ & No & No & $\begin{array}{c}.1005 * * * \\
(.0038)\end{array}$ & $\begin{array}{c}.1060 * * * \\
(.0038)\end{array}$ \\
\hline Out of Labor Force & & & $\begin{array}{c}-.0330 * * * \\
(.0014)\end{array}$ & $\begin{array}{l}.0002 \\
(.0015)\end{array}$ \\
\hline $\begin{array}{l}\text { Per-capita family } \\
\text { income }\end{array}$ & No & No & No & $\begin{array}{c}-.0002 * * * \\
(.0000)\end{array}$ \\
\hline
\end{tabular}




\section{TABLE IVA \\ Young AdulTs (18- TO 33-YEAR-OLDS) LIVING WITH THEIR PARENTS, SECOND-GENERATION IMMIGRANTS, 1994-2000 CPS \\ DEPENDENT VARIABLE: A DUMMY VARIABLE FOR A YOUNG ADULT LiVING AT HOME}

\begin{tabular}{|c|c|}
\hline \multirow{2}{*}{$\begin{array}{l}\text { Fraction of young adults } \\
\text { living at home in the } \\
\text { original European } \\
\text { country }\end{array}$} & $.2965 * * *$ \\
\hline & $(.0280)$ \\
\hline Male & $\begin{array}{c}.1304 * * * \\
(.004)\end{array}$ \\
\hline \multicolumn{2}{|l|}{ Education } \\
\hline Less than Diploma & $\begin{array}{c}-.0628 * * * \\
(.0027)\end{array}$ \\
\hline Diploma & $\begin{array}{c}-.0485^{* * * *} \\
(.0036)\end{array}$ \\
\hline \multicolumn{2}{|l|}{ Labor-market status } \\
\hline Unemployed & $\begin{array}{c}.0593 * * * \\
(.0090)\end{array}$ \\
\hline Out of Labor Force & $\begin{array}{c}.0674 * * * \\
(.0040)\end{array}$ \\
\hline$R^{2}$ & .326 \\
\hline $\begin{array}{ll}\text { a. } & \text { Robust standard err } \\
\text { b. } & \text { Sample size is 162, } \\
\text { c. } & \text { Other covariates inc } \\
& \text { state dummies, } 2 \mathrm{~m} \\
& \text { and a quadratic tern }\end{array}$ & $\begin{array}{l}\text { parenthesis. } \\
\text { in the regressions are } \\
\text { ndicators, } \\
\text { ge. }\end{array}$ \\
\hline
\end{tabular}




\section{TABLE IVB \\ Young Adults (16- TO 30-YEAR-OLDS) LIVING WITH THEIR PARENTS, SECOND-GENERATION IMMIGRANTS, CENSUS 1970 \\ DePENDENT VARIABLE: A DUMmy VARIABLE FOR A Young ADULT LiVING AT Home}

\begin{tabular}{|c|c|}
\hline \multirow{2}{*}{$\begin{array}{l}\text { Fraction of young adults } \\
\text { living at home in the } \\
\text { original European } \\
\text { country }\end{array}$} & $.3677 * * *$ \\
\hline & (.1057) \\
\hline Male & $\begin{array}{c}.0480^{* * * *} \\
(.0013)\end{array}$ \\
\hline \multicolumn{2}{|l|}{ Education } \\
\hline Diploma & $\begin{array}{c}.0573 * * * \\
(.0033)\end{array}$ \\
\hline Some college & $\begin{array}{c}.0199 * * * \\
(.0034)\end{array}$ \\
\hline \multicolumn{2}{|l|}{ Labor-market status } \\
\hline Unemployed & $\begin{array}{c}.0803 * * * \\
(.0036)\end{array}$ \\
\hline Out of Labor Force & $\begin{array}{c}-.0328 * * * \\
(.0013)\end{array}$ \\
\hline$R^{2}$ & .4012 \\
\hline $\begin{array}{ll}\text { a. } & \text { Robust standard err } \\
\text { b. } & \text { Sample size is 406, } \\
\text { c. } & \text { Other covariates in } \\
& \text { state dummies, } 2 \text { m } \\
& \text { a quadratic term for }\end{array}$ & $\begin{array}{l}\text { parenthesis. } \\
\text { in the regressions are } \\
\text { dicators, and }\end{array}$ \\
\hline
\end{tabular}




\section{TABLE V \\ Young AdUlTS (18- TO 33-YEAR-OlDS) LiVING WITH THEIR PARENTS, SECOND-GENERATION IMMIGRANTS, POOLED REGRESSION \\ DEPENDENT VARIABLE: A DUMMY VARIABLE FOR A Young ADULT LiVING AT HoME}

\begin{tabular}{|c|c|}
\hline \multicolumn{2}{|l|}{$\begin{array}{l}\text { Dummies for all } \\
\text { countries }(\beta)\end{array}$} \\
\hline \multirow[t]{2}{*}{ Portugal } & $.0602^{* *}$ \\
\hline & $(.0259)$ \\
\hline \multirow[t]{2}{*}{ Italy } & $.0623^{* * *}$ \\
\hline & $(.0067)$ \\
\hline \multirow[t]{2}{*}{ Greece } & $.0440^{* *}$ \\
\hline & $(.0177)$ \\
\hline \multirow[t]{2}{*}{ Spain } & .0337 \\
\hline & $(.0317)$ \\
\hline \multirow[t]{2}{*}{ Ireland } & $.0541^{* * *}$ \\
\hline & $(.0128)$ \\
\hline \multirow[t]{2}{*}{ Poland } & $.0652^{* * *}$ \\
\hline & $(.0111)$ \\
\hline \multirow[t]{2}{*}{ France } & -.0083 \\
\hline & $(.0288)$ \\
\hline \multirow[t]{2}{*}{ Germany } & .0032 \\
\hline & $(.0084)$ \\
\hline \multirow[t]{2}{*}{ Netherlands } & -.0030 \\
\hline & $(.0226)$ \\
\hline \multirow[t]{2}{*}{ Scandinavian Europe } & .0081 \\
\hline & $(.0102)$ \\
\hline \multirow[t]{2}{*}{ UK } & $.0250^{* *}$ \\
\hline & $(.0102)$ \\
\hline \multicolumn{2}{|l|}{$\begin{array}{l}\text { Dummies for all } \\
\text { countries interacted with } \\
\text { a year-2000 dummy } \\
(\gamma)\end{array}$} \\
\hline \multirow[t]{2}{*}{ Portugal 2000} & $.1380^{* * *}$ \\
\hline & $(.0388)$ \\
\hline \multirow[t]{2}{*}{ Italy 2000} & $.0708^{* * *}$ \\
\hline & $(.0177)$ \\
\hline \multirow[t]{2}{*}{ Greece 2000} & $.1025^{* * *}$ \\
\hline & $(.0329)$ \\
\hline \multirow[t]{2}{*}{ Spain 2000} & $.1073 *$ \\
\hline & $(.0674)$ \\
\hline \multirow[t]{2}{*}{ Ireland 2000} & -.0151 \\
\hline & $(.0300)$ \\
\hline \multirow[t]{2}{*}{ Poland 2000} & -.0211 \\
\hline & $(.0324)$ \\
\hline
\end{tabular}


TABLE V

(CONTINUED)

\begin{tabular}{|c|c|}
\hline France 2000 & $\begin{array}{c}.0524 \\
(.0539)\end{array}$ \\
\hline Germany 2000 & $\begin{array}{l}-.0095 \\
(.0198)\end{array}$ \\
\hline Netherlands 2000 & $\begin{array}{l}-.0048 \\
(.0523)\end{array}$ \\
\hline Scandinavian Europe & .0152 \\
\hline 2000 & $(.0438)$ \\
\hline UK 2000 & $\begin{array}{l}-.0282 \\
(.0236)\end{array}$ \\
\hline Male & $\begin{array}{l}-.0002 \\
(.0010)\end{array}$ \\
\hline \multicolumn{2}{|l|}{ Education } \\
\hline Diploma & $\begin{array}{c}.0400 * * * \\
(.0017)\end{array}$ \\
\hline Some College & $\begin{array}{c}.0330 * * * \\
(.0018)\end{array}$ \\
\hline \multicolumn{2}{|l|}{ Labor-market status } \\
\hline Unemployed & $\begin{array}{c}.0620^{* * *} \\
(.0029)\end{array}$ \\
\hline Out of Labor Force & $\begin{array}{c}-.0668^{* * *} \\
(.0011)\end{array}$ \\
\hline \multicolumn{2}{|l|}{$p$-values } \\
\hline$\gamma_{j}=0$ & 0.0000 \\
\hline $\begin{array}{l}\text { Southern European } \\
\text { countries }=0\end{array}$ & 0.0000 \\
\hline $\begin{array}{l}\text { Ireland, Poland, } \\
\text { France, Germany, } \\
\text { Netherlands, } \\
\text { Scandinavian } \\
\text { Europe }=0\end{array}$ & 0.8378 \\
\hline$R^{2}$ & .249 \\
\hline
\end{tabular}

a. Scandinavian Europe includes Denmark, Finland, Norway and Sweden.

b. Robust standard errors in parentheses.

c. Sample size is 556,224 .

d. Other covariates included in the regressions are state dummies, state dummies interacted with a year 2000 dummy, metro indicator, and a quadratic term for age. 


\section{APPENDIX 1}

TABLE A1

COUNTRY SUMMARY STATISTICS,

CENSUS 1970 (AgE GROUP 18-33)

\begin{tabular}{lccccccccccc}
\hline \hline \multicolumn{1}{c}{ Country } & Obs. & $\begin{array}{c}\text { Fraction } \\
\text { living at } \\
\text { home }\end{array}$ & Age & $\begin{array}{c}\text { Up to 12 } \\
\text { years of } \\
\text { education }\end{array}$ & $\begin{array}{c}\text { Some } \\
\text { college }\end{array}$ & $\begin{array}{c}\text { College } \\
\text { plus }\end{array}$ & $\begin{array}{c}\text { Fraction } \\
\text { employed }\end{array}$ & $\begin{array}{c}\text { Fraction } \\
\text { Unemployed }\end{array}$ & $\begin{array}{c}\text { Out of } \\
\text { Labor } \\
\text { Force }\end{array}$ & $\begin{array}{c}\text { Armed } \\
\text { force }\end{array}$ \\
\hline Portugal & 198 & .2525 & 26.17 & .77 & .21 & .02 & .61 & .025 & .333 & .03 \\
Greece & 385 & .2337 & 26.31 & .459 & .48 & .06 & .667 & .031 & .288 & .01 \\
Italy & 3168 & .2414 & 26.97 & .647 & .311 & .04 & .62 & .02 & .335 & .018 \\
Spain & 127 & .2047 & 26.11 & .653 & .314 & .03 & .63 & .023 & .307 & .04 \\
Ireland & 865 & .2346 & 26.95 & .596 & .351 & .05 & .62 & .026 & .334 & .016 \\
Poland & 1184 & .2652 & 26.28 & .448 & .451 & .099 & .60 & .023 & .36 & .017 \\
France & 141 & .1773 & 25.63 & .567 & .397 & .035 & .588 & .021 & .35 & .042 \\
Germany & 1633 & .1739 & 26.30 & .532 & .409 & .058 & .60 & .018 & .355 & .03 \\
Netherlands & 233 & .2145 & 25.59 & .60 & .369 & .03 & .64 & .038 & .304 & .017 \\
Scandinavian & 959 & .1501 & 26.80 & .56 & .396 & .043 & .622 & .023 & .316 & .036 \\
Europe & & & & & & & & .036 & .03 \\
UK & 1301 & .2175 & 26.15 & .515 & .423 & .06 & .627 & .026 & .313 & .033 \\
USA & 382947 & .2313 & 24.63 & .634 & .341 & .025 & .59 & .036 & .340 & .035 \\
\hline \hline
\end{tabular}


TABLE A2

COUNTRY SUMMARY STATISTICS,

CPS 1994-2000 (AGE GROUP 18-33)

\begin{tabular}{lcccccccccc}
\hline \multicolumn{1}{c}{ Country } & Obs. & $\begin{array}{c}\text { Fraction } \\
\text { living at } \\
\text { home }\end{array}$ & Age & $\begin{array}{c}\text { Less } \\
\text { than } \\
\text { Diploma }\end{array}$ & Diploma & B.A & $\begin{array}{c}\text { Master } \\
\text { and } \\
\text { more }\end{array}$ & $\begin{array}{c}\text { Fraction } \\
\text { Employed }\end{array}$ & $\begin{array}{c}\text { Fraction } \\
\text { Unemployed }\end{array}$ & $\begin{array}{c}\text { Out of } \\
\text { Labor } \\
\text { Force }\end{array}$ \\
\hline Portugal & 205 & .6099 & 23.32 & .19 & .29 & .5121 & .005 & .7514 & .082 & .165 \\
Greece & 216 & .4901 & 24.68 & .07 & .199 & .6574 & .074 & .6497 & .016 & .333 \\
Italy & 648 & .4413 & 26.16 & .06 & .279 & .6095 & .0524 & .7822 & .052 & .165 \\
Spain & 54 & .3401 & 25.57 & .11 & .185 & .6481 & .055 & .6666 & .092 & .240 \\
Ireland & 194 & .3383 & 27.24 & .041 & .2268 & .6546 & .077 & .8622 & .053 & .083 \\
Poland & 145 & .3231 & 26.68 & .082 & .2344 & .6206 & .062 & .7916 & .016 & .191 \\
France & 73 & .3267 & 24.86 & .1643 & .1780 & .6438 & .013 & .7457 & .050 & .203 \\
Germany & 440 & .2864 & 25.66 & .1090 & .2818 & .5431 & .065 & .7513 & .040 & .208 \\
Netherlands & 52 & .3095 & 25.69 & .0576 & .1346 & .7115 & .096 & .8076 & .019 & .173 \\
Scandinavian & 68 & .1857 & 26.97 & 0 & .1911 & .7205 & .088 & .6617 & .044 & .294 \\
Europe & & & & & & & & & & .043 \\
UK & 272 & .2267 & 26.58 & .073 & .2904 & .5514 & .084 & .8101 & .023 & .166 \\
USA & 160716 & .2753 & 25.83 & .1345 & .3326 & .4998 & .032 & .7527 & .053 & .193 \\
\hline \hline
\end{tabular}

Source: CPS 1994-2000, March Demographic Supplement 


\section{TABLE A3 \\ PreferenCes FOR HOME OWNERSHIP ACROSS ETHNiCITIES, CPS 1994-2000}

DEPENDENT VARIABLE: A DUMMY VARIABLE FOR HOME OWNERSHIP

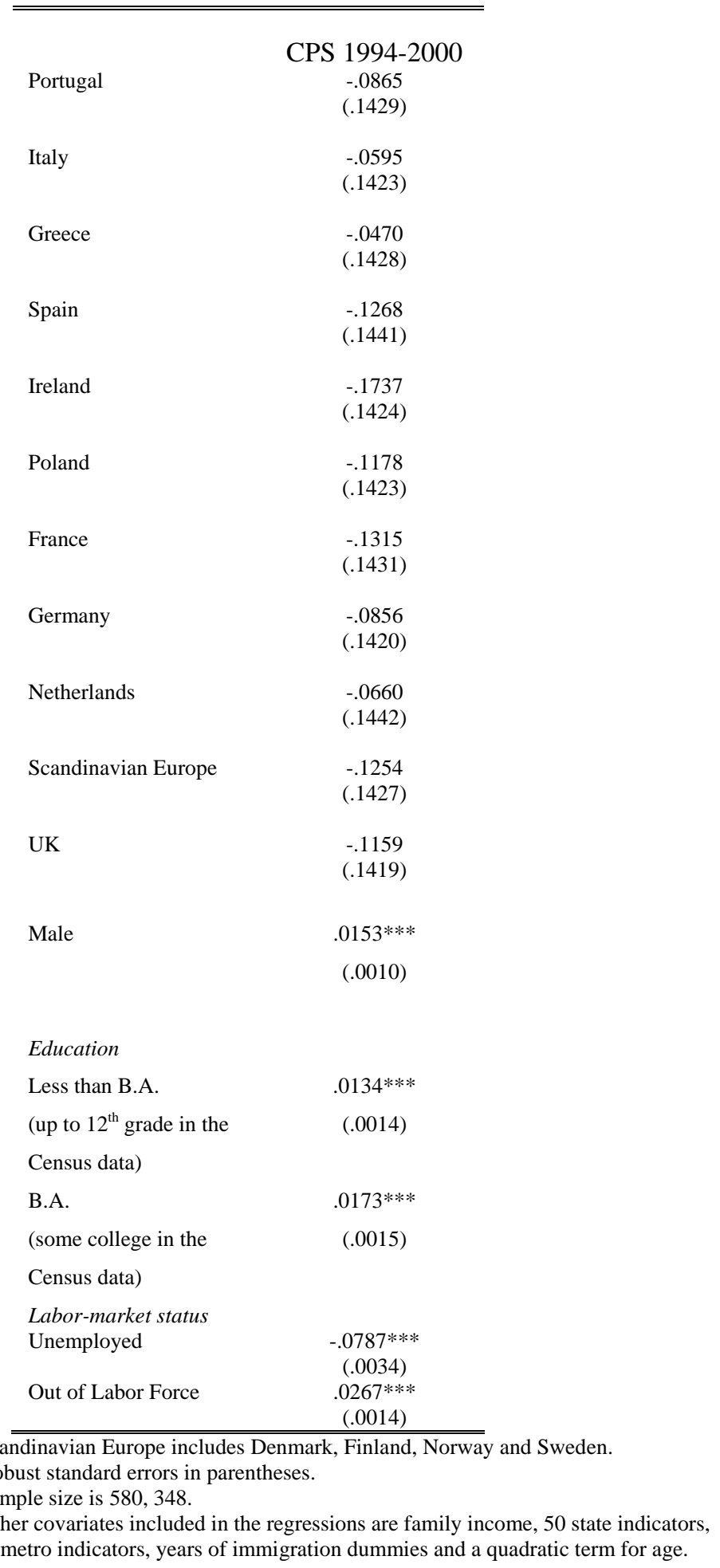




\section{TABLE A4}

Young Adults Living With Their PARENTs, 18 TO 33 YeAr Olds, SECOND-GENERATION IMMIGRANTS

DEPENDENT VARIABLE: A DUMMY VARIABLE FOR A Young ADULT LiVING AT HOME

$\begin{array}{lcc} & \text { CENSUS } 1970 & \text { CPS } 1994-2000 \\ \text { Southern Europe } & .0320^{* * *} & .1046 * * * \\ & (.0089) & (.0195) \\ \text { Western Europe } & -.0151 & -.0397 \\ & (.0114) & (.0258) \\ \text { Scandinavian Europe+ UK } & .0108 & -.0617^{*} \\ & (.0111) & (.0341) \\ \text { Ireland+Poland } & .0547 * * * & .0241 \\ & (.0125) & (.0316) \\ \text { Southern Europe*Female } & .0274^{* *} & .0201 \\ \text { Western Europe*Female } & (.0121) & (.0273) \\ & .0209 & .0587 * \\ \text { (Scandinavian Europe+UK)*Female } & (.0153) & (.0350) \\ & .0045 & .0487 \\ \text { (Ireland+Poland)*Female } & (.0146) & (.0413) \\ \text { Female } & -.0068 & .0241 \\ & (.0168) & (.0316) \\ & -.0434 * * * & -.1225 * * * \\ & (.0014) & (.0022)\end{array}$

Education

Less than B.A.

$.0512^{* * *} \quad .0472^{* * *}$

(up to $12^{\text {th }}$ grade in the Census data)

(.0027)

(.0057)

B.A.

$.0203 * * *$

$.0542^{* * *}$

(some college in the Census data)

(.0028)

(.0047)

Labor-market status

Unemployed

$.1060^{* * *} \quad .0717^{* * *}$

(.0038) (.0055)

Out of Labor Force

.0002

(.0015)

Per-capita family income

$-.0002 * * *$

$.0788^{* * *}$

(.0029)

(.000)

$(.000)$

a. Scandinavian Europe includes Denmark, Finland, Norway and Sweden.

b. Robust standard errors in parentheses.

c. Sample size is 393,141 for Census 1970 and 163,076 for CPS 1994-2000

d. Other covariates included in the regressions are family income, 50 state indicators,

3 metro indicators and a quadratic term for age.

e. Per-capita income is defined as the total family income divided by the number of family members. I convert the reported family income data from seven CPS samples from current dollars into constant-1995 dollars prior to pooling across years 
TABLE A5: SUMMARY STATISTICS

PARENTS OF YOUNG ADULTS LIVING AT HOME BY IMMIGRANT GROUP

CPS 1994-2000

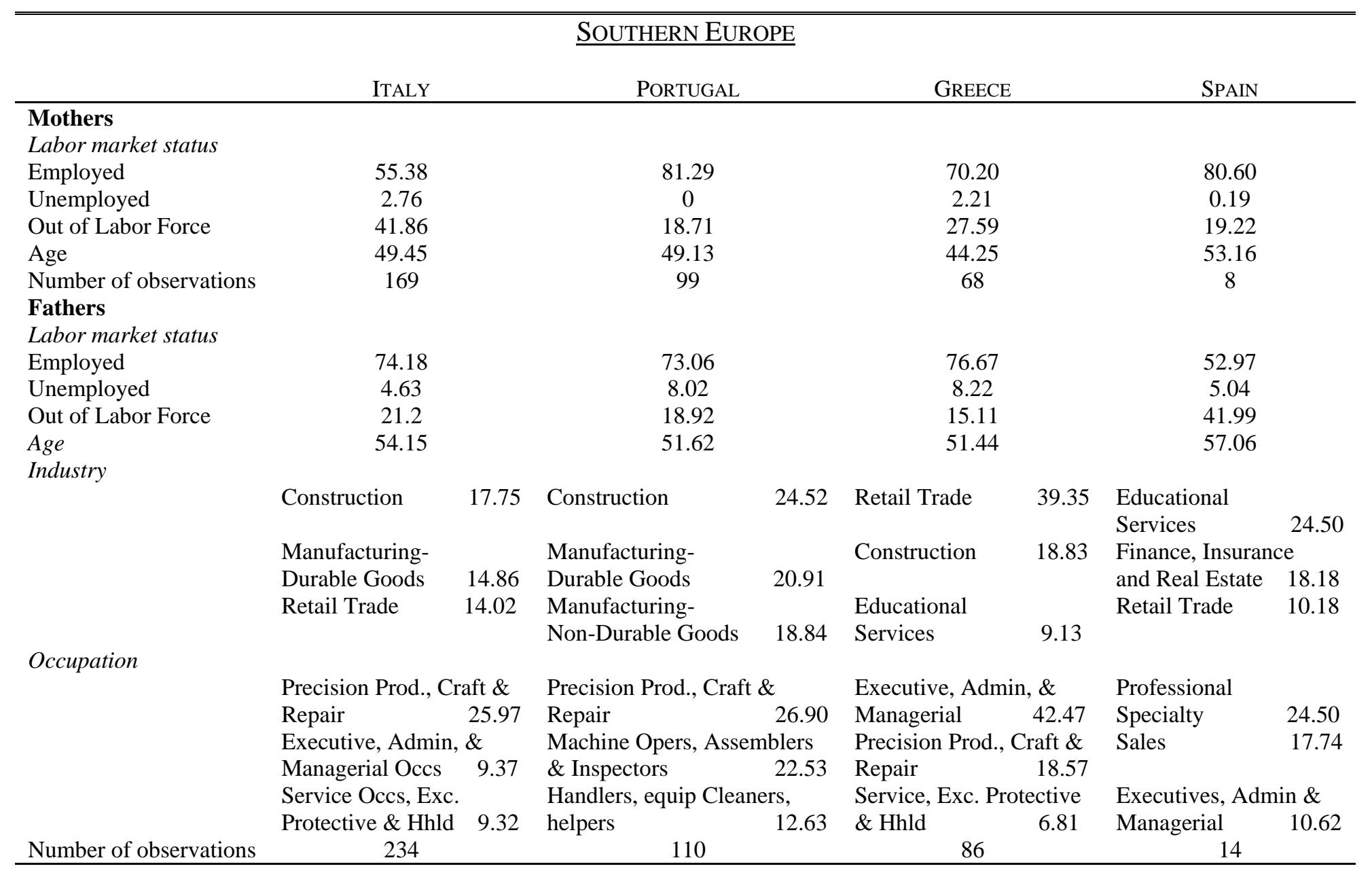


TABLE A5

(CONTINUED)

\section{WESTERN EUROPE AND IRELAND}

\begin{tabular}{|c|c|c|c|c|c|c|c|c|}
\hline & \multicolumn{2}{|l|}{ GERMANY } & \multicolumn{2}{|l|}{ FRANCE } & \multicolumn{2}{|c|}{ NETHERLANDS } & \multicolumn{2}{|c|}{ IRELAND } \\
\hline \multicolumn{9}{|l|}{ Mothers } \\
\hline \multicolumn{9}{|l|}{ Labor market status } \\
\hline Employed & \multicolumn{2}{|l|}{70.21} & \multicolumn{2}{|l|}{100} & \multicolumn{2}{|l|}{41.26} & \multicolumn{2}{|l|}{53.39} \\
\hline Unemployed & \multicolumn{2}{|l|}{2.36} & \multicolumn{2}{|l|}{0} & \multicolumn{2}{|l|}{0} & \multicolumn{2}{|l|}{0.07} \\
\hline Out of Labor Force & \multicolumn{2}{|l|}{27.42} & \multicolumn{2}{|l|}{0} & \multicolumn{2}{|l|}{58.75} & \multicolumn{2}{|l|}{47.54} \\
\hline Age & \multicolumn{2}{|l|}{47.87} & \multicolumn{2}{|l|}{49.67} & \multicolumn{2}{|l|}{55} & \multicolumn{2}{|l|}{51.56} \\
\hline Number of observations & \multicolumn{2}{|l|}{76} & \multicolumn{2}{|l|}{13} & \multicolumn{2}{|l|}{14} & \multicolumn{2}{|l|}{35} \\
\hline \multicolumn{9}{|l|}{ Fathers } \\
\hline \multicolumn{9}{|l|}{ Labor market status } \\
\hline Employed & \multicolumn{2}{|l|}{89.18} & \multicolumn{2}{|l|}{100} & \multicolumn{2}{|l|}{69.79} & \multicolumn{2}{|l|}{76.86} \\
\hline Unemployed & 0 & & & & 0 & & 1.18 & \\
\hline Out of Labor Force & 10.82 & & & & 30.21 & & 21.96 & \\
\hline Age & 51.55 & & 52.23 & & 57.85 & & 55.67 & \\
\hline & Retail Trade & 15.99 & Public Administration & 38.03 & Retail Trade & 25.90 & Construction & 17.65 \\
\hline & Public Administ. & 12.85 & Social Services & 17.55 & $\begin{array}{l}\text { Manufacturing } \\
\text { Durable }\end{array}$ & 24.59 & Transportation & 17.29 \\
\hline & Construction & 7.76 & Retail Trade & 12.70 & Educational & & Manufacturing & \\
\hline & & & & & Services & 11.07 & Durable Goods & 13.28 \\
\hline Occupation & & & & & & & & \\
\hline & Executive, Admin & & Precision Prod., Craft c & Ind & Sales & 17.98 & Precision Prod., & Craft \\
\hline & Managerial & 35.32 & Repair & 24.82 & & & and Repair & 24.78 \\
\hline & Precision Prod., C & raft \& & Technicians and Relate & & Mach. Opers, A & emb. & Admin. Support & Incl. \\
\hline & Repair & 15.80 & Support & 20.18 & and Insps. & 15.44 & Clerical & 17.42 \\
\hline & Professional Spec & alty & Executive, Admin, \& & & Executive, Adm & & Executive, Adm & n \& \\
\hline & Occs & 12.54 & Managerial & 19.69 & Managerial & 11.07 & Managerial & 15.24 \\
\hline Number of observations & 95 & & 17 & & 14 & & 49 & \\
\hline
\end{tabular}


TABLE A5

(CONTINUED)

\section{SCANDINAVIAN EUROPE, UK, NATIVES AND POLAND}

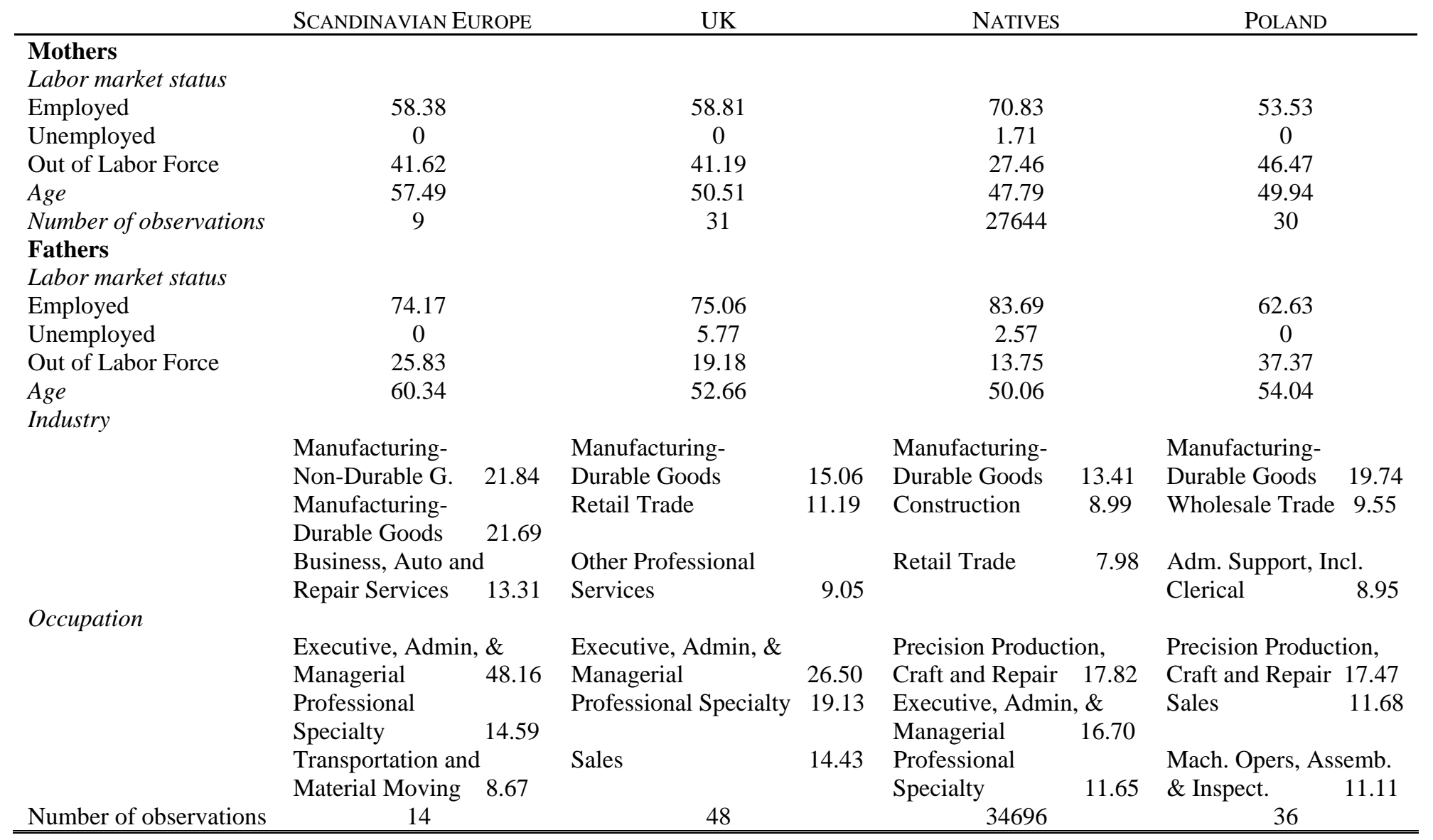


APPENDIX 2

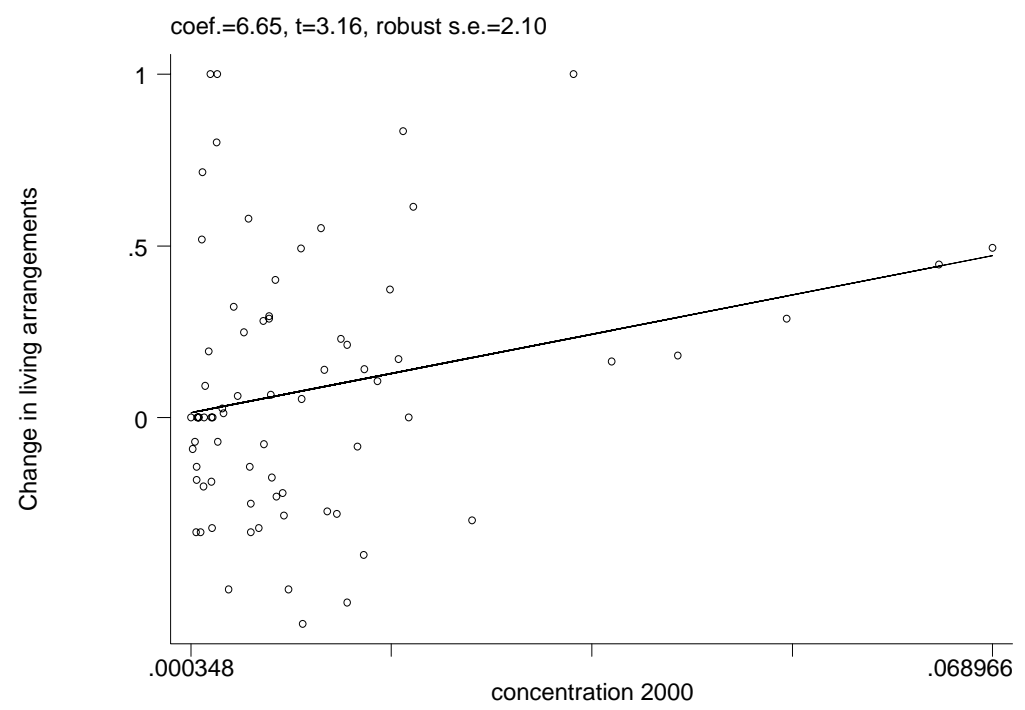

FIGURE II

Correlation between the Change in the Fraction of Young Adults Living at Home from 1970 to 2000 and the Concentration Level of Immigrants (2000) at the PMSA Level for Southern European Second Generation Immigrants, 18-33 Years Old

\section{WESTERN EUROPE}

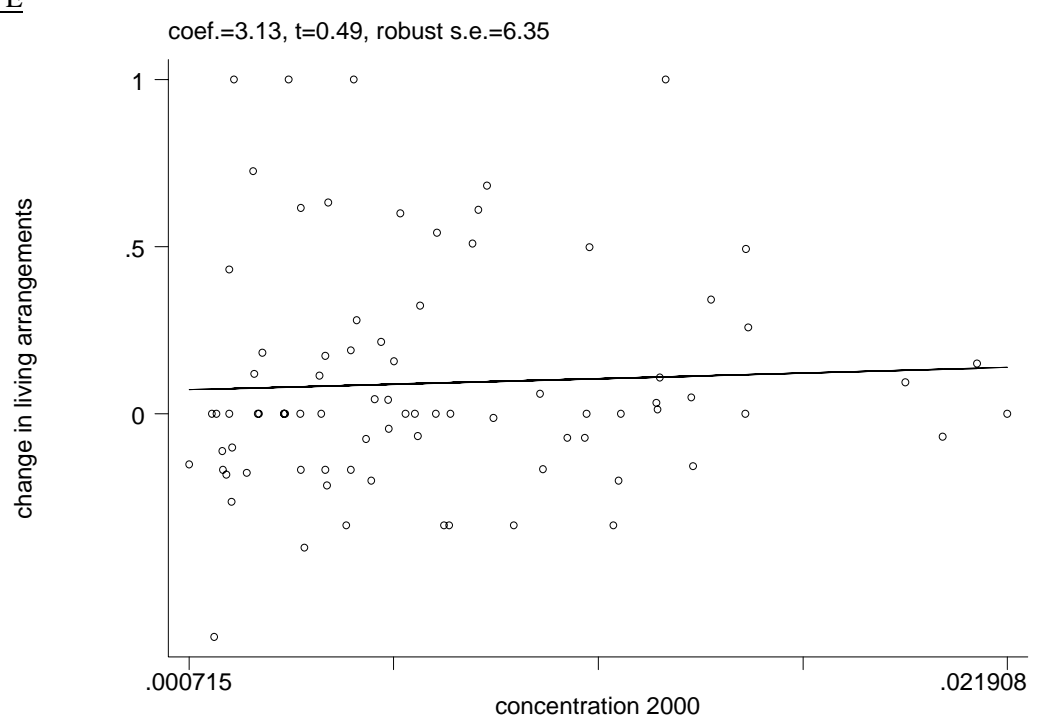

FIGURE III

Correlation between the Change in the Fraction of Young Adults Living at Home from 1970 to 2000 and the Concentration Level of Immigrants (2000) at the PMSA Level for Western European Second Generation Immigrants, 18-33 Years Old 


\section{NORTHERN EUROPE}

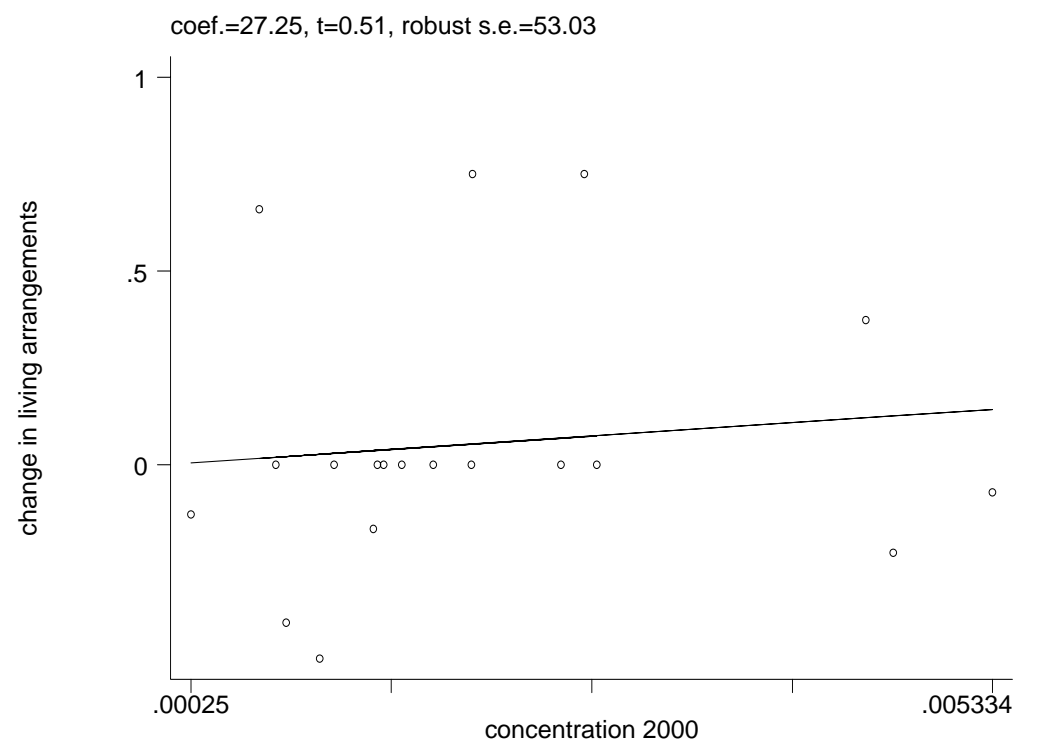

FIGURE IV

Correlation between the Change in the Fraction of Young Adults Living at Home from 1970 to 2000 and the Concentration Level of Immigrants (2000) at the PMSA Level for Northern European Second Generation Immigrants, 18-33 Years Old 